\title{
NATIONAL AND REGIONAL PERSISTENCE OF HIGH PERFORMANCE AGRICULTURAL BANKS IN THE 1980s
}

\author{
Douglas G. Duncan and George B. Wallace*
}

\begin{abstract}
The decline of the agriculture sector in the mid-1980s was concurrent with the increase of bank failures. Performance of banks specializing in agricultural lending mirrored sector performance. However, a subgroup of banks continued to lend to agriculture and maintained superior performance over the entire decade. Characteristics of these high performance banks and their lower performing counterparts are compared annually at both the National and United States Department of Agriculture Cropping Region level to identify factors leading to superior performance. Ratio analysis is performed using the criteria of solvency, profitability, liquidity, and efficiency. Selected ratios are employed in a logit model for classifying banks according to high or nonhigh performance. Model results were strong at the national level but weaker at the regional level possibly because of differences in agricultural production patterns and state banking laws. High-performance banks controlled costs, made less risky loans, and employed resources more efficiently.
\end{abstract}

\section{INTRODUCTION}

The decade of the 1980s was a roller coaster for commercial banks. Bank failures, relatively rare since the 1930 s, became commonplace in the 1980 s with 1,053 banks failing. The performance of the economy varied widely, affecting some sectors more than others. The travails of the energy and agriculture sectors and the banks serving them were well chronicled (Duncan et al. 1990; Melichar 1987). The number of agricultural banks declined 19 percent during this time period. In general, bank performance declined from the high profitability experienced at the decade's onset to a low point at mid-decade to a slow recovery at the decade's end.

Sector specialization and the concurrent lack of loan portfolio diversification, especially among small banks, were cited as prime causes of bank failure, as were lack of management sophistication and increased competition. These causes of failure are currently being used to encourage the radical restructuring of the banking system; several of the areas proposed for restructuring include the elimination of both intra- and interstate bank branching restrictions and major industry consolidation.

\footnotetext{
*Agricultural Economists, Economic Research Service, U.S. Department of Agriculture.
} 
Yet, throughout the decade, there was evidence of continued profitability among many small banks, including many agricultural banks that benefitted from the farm credit provided by small banks. Thus, there existed simultaneously highperformance agricultural banks and significant numbers of agricultural bank failures.

The increase in failures generated a great deal of research into identification of early indicators of bank failure (e.g., Gajewski 1987; Bovenzi et al. 1983), which was natural because failures affected both deposit insurance reserves and bank debt and equity holders. However, relatively less work was done to determine the factors leading to sustained high performance.

Ford and Olson (1978) identified bank maximization of revenues (effective pricing strategies and maximizing tax-exempt income), expense control (minimizing fixed expense, excluding employee compensation, and efficient employment of personnel), and consistently good management (effective planning, organization, and control) as characteristics of superior performers.

Goldman Sachs (1987) evaluated 46 large banks over 1984-1986 and identified 12, including 1 multinational and 11 regional multibank holding companies, that earned more than a 1 percent rate of return on assets (ROA). However, one year later, after accounting for large additions to loss reserves for less developed country nonperforming loans, only four of these banks still earned more than 1 percent ROA.

A study of banks in the Eleventh Federal Reserve District (Clair 1987) identified a number of banks that were high performers between 1981 and 1985. In this case, high performers meant those banks in the top 10 percent of return on assets. Three management strategies were observed among these banks: expense control, commercial real estate lending, and conservative (less) lending. It should be noted that the study period ends in 1985, which is prior to the bulk of the 1980 s bank failures. Furthermore, the Eleventh District is heavily influenced by its largest state, Texas, which subsequently dominated the bank failures list. Finally, commercial real estate began a precipitous decline in the late 1980s and early 1990s that was not incorporated into the study period.

Inquiries about the effect of market concentration on bank profits have been inconclusive. Whalen (1987) studied banks in a two-state area during 1982-84. While not concentrating on a specific "high-performance" group, he measured market concentration in rural areas using the Herfindahl index and estimated its relationship to ROA but found no explanatory power.

Gup and Walter (1989) studied small banks during 1982-87 and classified high performers as those earning ROA of more than 1.5 percent. They suggested collusion (market concentration), greater risk-taking, random events, and unique qualities as potential explanations for "persistent profits." Their results were con- 
sistent with Whalen's regarding market concentration, and they agreed with Ford and Olson's finding that unique qualities and management abilities led to high performance. There was, however, no control over banks entering and exiting the study group during the period under consideration.

This study will add to the existing literature in several ways. It will utilize a longer time frame, thus reducing the probable contribution of random events to rate of return on average assets (ROAA). It will evaluate the same bank groups over the entire period, thus improving consistency of measurement. It will span an economic cycle within a sector, thus giving greater opportunity for superior management to reveal itself. It will investigate a group of banks that consistently maintained a high level of ROAA while holding a higher-than-average concentration of agricultural loans in their portfolio.

The objective of this study is to identify those factors that led to sustained high profitability among agricultural banks over an economic cycle including sectoral decline and recovery. We investigate characteristics of consistently profitable agricultural banks in comparison with their lower performing counterparts over the entire 1980s decade. Furthermore, we investigate whether these factors are reliable in identifying high-performance banks at the regional level, using United States Department of Agriculture (USDA) crop reporting regions. The remainder of the paper will include a description of the data and methodology employed in the analysis, a presentation of results of ratio analysis, as well as national and regional models, and a statement of conclusions and implications.

\section{DATA}

Data from the December 31, 1980-89 quarterly Report of Income and Condition (call reports) of the Board of Governors of the Federal Reserve System were utilized. The banks included in this study had to be classified as agricultural during each of the 10 years of the study period to ensure that the bank's portfolio reflected a maintained higher-than-average commitment to agriculture, even when sector performance was at its lowest. The average ratio of agricultural loans to total loans ranged from a high of 18.45 (1980) to a low of 15.60 (1987). All banks included in this study also were chartered before January 1,1977 , and were still in existence on December 31, 1989, which was a control for the effects of both failed and de novo banks on aggregate results during the study period.

To achieve the "high performance bank" or HPB classification, a bank must have earned a minimum 1.1 percent ROAA during each year of the study period. Those banks not achieving this standard are classified as "nonhigh performance banks" or NHPBs. Within the banking industry, an ROAA of 1 percent is con- 
sidered a desirable goal for long-term profitability. Agricultural banks entered the decade eaming an average ROAA of 1.1 percent. Thus, it was felt that the ability to maintain this level of performance, even as the agricultural economy stagnated, demonstrated superior performance.

These criteria identified a total of 3,103 agricultural banks over the decade, including $204 \mathrm{HPBs}$ and 2,899 NHPBs. Thus, HPBs comprise 6.6 percent of all agricultural banks included in the study.

\section{METHODOLOGY}

Aspects of balance sheets and income statements of HPBs and NHPBs will be compared to illustrate their relative sizes and portfolio compositions. Mean values of financial ratios will be calculated for the two bank groups. Ratio analysis will be performed using the classic criteria of profitability, solvency, efficiency, and liquidity (Sinkey 1989). Mean ratio values of HPBs will be compared with NHPBs using t-tests to identify variables for constructing a model to estimate the probability of a particular agricultural bank being an HPB.

There exists the potential for variation in agricultural bank performance due to regional factors such as 1) differences in banking laws and regulation, 2) credit requirements for agricultural production, 3 ) impact of the decline of the agricultural economy, and 4) regional effects of macroeconomic events.

Agricultural banks will be sorted by the 10 USDA crop reporting regions and by HPB/NHPB classification within each region for ratio means comparisons. Model results estimating the probability of being an HPB will be compared across regions.

The binary nature of the HPB variable makes it amenable to the logit modeling technique. The model is estimated in the form shown in Equation 1 (Pindyck and Rubinfeld 1981).

$$
\log \left(P_{i} /\left(1-P_{i}\right)\right)=\alpha_{o}+\sum_{i=1}^{N} \beta_{i} X_{i}
$$

where: $P_{i}=$ the probability that the ith bank is an HPB

$X_{i}=$ the ith independent variable

The actual probability of a bank being an HPB is in the general form shown in Equations 2 and 3. 


$$
P_{i}=1 /\left(1+e^{-2} i\right)
$$

where

$$
Z_{i}=\alpha+\sum_{i=1}^{N} \beta_{i} X_{i}
$$

Thus, $P_{i}$ is the probability that a particular agricultural bank will be a high-performance agricultural bank given attribute $X_{i}$.

The logit model has two advantages that make it a good candidate for this study. First, it restricts the probabilities to fall within the range 0 to 1 , whereas a linear probability model, for example, does not. Second, as parameter estimates are obtained through maximum likelihood techniques, it can be shown that they are asymptotically normal, thus permitting the use of the t-test in hypothesis testing.

\section{Ratio Analysis Results}

HPBs achieved a decade average ROAA of 1.8 percent, with a high of 1.98 percent in 1983 and a low of 1.64 percent in 1989. NHPBs averaged ROAA of 0.88 percent, with a high of 1.39 percent in 1981 and a low of 0.39 percent in 1986. NHPB performance declined dramatically in the mid-1980s before beginning to recover. Interestingly, the ROAA for HPBs was basically constant the last three years and lower than at the outset of the decade. Average asset size of the two bank groups converged over the decade. HPBs demonstrated relatively constant growth, albeit from a lower base, while NHPB growth rate tapered off in the latter half of the decade. Equity capital levels were greater and increased at HPBs throughout the decade. This measure of capital is the most important because it represents the stake investors have in the business.

One striking difference between the two bank groups was the relative proportion of loans and securities held in their portfolios over the decade. NHPBs had a consistently higher commitment to loans relative to securities than HPBs. The two groups' proportional allotments to loans and securities moved in a roughly parallel manner over the decade. However, as the agricultural sector downturn approached, the HPBs were somewhat swifter to shift their portfolios toward securities and increase capital-to-asset ratios. The higher capital-to-asset ratios, as well as a relatively higher proportion of securities to loans, indicate a lower risktaking profile for the HPBs over this time period. 
Ratios used in the analysis of solvency, profitability, liquidity, and efficiency are defined in Table 1. In each case, the mean values of these ratios are reported in Table 2 and are based upon the unweighted mean of the ratio for each bank group. These mean values were chosen because they identify important and statistically significant differences between HPBs and NHPBs.

Since the banks evaluated in this study are, by definition, solvent over the entire decade, this criterion gets the least attention in the analysis. However, solvency is the basic statement of a bank's capacity for survival. Profitability impacts long-term survival and growth as well as indicating returns to owners. Liquidity is important to a bank, given the random nature of deposit withdrawals. Since government securities are readily marketable, a bank is heavily dependent upon them to maintain its liquidity. The degree of liquidity is also dependent on the composition of those securities. Likewise, on the liability side, deposit composition affects liquidity. Efficiency is the evaluation of the effectiveness of the employment of resources in generating profitability. The degree of efficiency governs the bank's performance relative to its peers.

Average equity (one measure of solvency) of HPBs grew at roughly double the rate of NHPBs, which is consistent with the fact that HPBs earned roughly double the ROAA of NHPBs over the decade. The equity multiplier indicates HPBs also decreased leverage throughout the decade, while NHPBs increased it slightly. HPB profit margins were higher and less variable throughout the decade. Loan loss rates for both bank groups followed the agricultural sector's health, but the less risky and smaller loan portfolios reflected their greater profitability. The loan-to-deposit ratio, a traditional measure of liquidity, indicates HPBs were more liquid throughout, thus allowing them to adapt more readily to changing economic conditions. While the "available upon demand" characteristic of demand deposits can contribute to liquidity problems, demand deposits also contribute to lower interest expenses and higher net interest margins. Efficient banks must control operating expenses, both interest and noninterest. In both areas, HPBs were superior, although their advantage on interest expense declined. However, HPB advantage in control of noninterest expense increased over the decade. One way of controlling noninterest expense is to deploy employees more effectively, and HPBs consistently held more assets per employee than NHPBs.

Intraregional comparison of HPB and NHPB ratios through the use of t-tests yielded no qualitative or conceptually inconsistent differences between the regional and national levels. However, ratio results do not indicate whether performance varies within a bank group across regions. The explanatory power of particular ratios across regions is investigated in the logit modelling section. 
TABLE 1

Ratio Definitions

\begin{tabular}{|c|c|c|}
\hline Criteria & Ratio & Components \\
\hline \multirow[t]{2}{*}{ Solvency } & Primary capital-to-asset & (Primary capital/average assets) $* 100.0$ \\
\hline & equity multiplier & Average assets/average equity \\
\hline \multirow[t]{6}{*}{ Profitability } & Profit margin & (Net income/total income)*100.0 \\
\hline & Loss rate & (Net charge-offs/average loans)*100.0 \\
\hline & Net interest margin & (Net interest income/average assets)* 100.0 \\
\hline & Net noninterest margin & (Net noninterest income/average assets) $* 100.0$ \\
\hline & Adjusted net interest & ((Net income-net charge-offs + (tax-exempt income) \\
\hline & margin & $(1$-marginal tax rate) $) /$ average assets $) * 100.0$ \\
\hline \multirow[t]{4}{*}{ Liquidity } & Loan-to-deposit & (Loans/deposits)*100.0 \\
\hline & Municipals-to-securities & (Municipals/securities)*100.0 \\
\hline & $\begin{array}{l}\text { Demand deposits-to- } \\
\text { total liabilities }\end{array}$ & 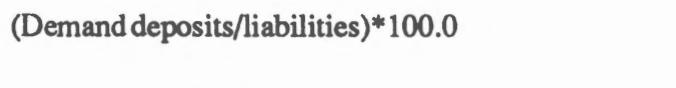 \\
\hline & Securities-to-assets & (Securities/assets)*100.0 \\
\hline \multirow[t]{6}{*}{ Efficiency } & Debt service & (Interest income/interest expense)*100.0 \\
\hline & Times interest earned & $\begin{array}{l}\text { ((Operating income-provision for losses)/ } \\
\text { interest expense) } * 100.0\end{array}$ \\
\hline & $\begin{array}{l}\text { Average deposit interest } \\
\text { rate }\end{array}$ & (Deposit interest expense/deposits)*100.0 \\
\hline & $\begin{array}{l}\text { Interest expense-to-avg. } \\
\text { assets }\end{array}$ & (Interest expense/average assets) $* 100.0$ \\
\hline & $\begin{array}{l}\text { Noninterest expense-to- } \\
\text { average assets }\end{array}$ & (Noninterest expense/average assets) $* 100.0$ \\
\hline & Assets per employee & (Assets/employee) \\
\hline
\end{tabular}

\section{Modelling Probability of High Performance}

The ratio analysis section reported 17 ratios, the means of which were statistically significantly different. These variables covered the spectrum of solvency, profitability, liquidity, and efficiency. The construction of these ratios guaranteed that many of them were highly correlated, which affected final selection of variables for the logit model.

Table 3 presents estimates for the model using national data for each year from 1981 to 1989. Variables selected for inclusion in the final model include 1) loan-to-deposit ratio (LTDG); 2) demand deposit-to-total liability ratio (DDTL); 3) noninterest expense-to-average asset ratio (NIEAA); 4) equity multi- 
TABLE 2

Selected Ratios By Criteria and High Performance Banks Versus Nonhigh Performance Banks, 1980-89

\begin{tabular}{|c|c|c|c|c|c|c|c|c|c|c|c|}
\hline Criteria / Ratio & & 1980 & 1981 & 1982 & 1983 & 1984 & 1985 & 1986 & 1987 & 1988 & 198 \\
\hline \multicolumn{12}{|l|}{ Solvency } \\
\hline Primary & HPB & 11.5 & 11.7 & 12.2 & 12.9 & 13.5 & 13.7 & 13.7 & 14.2 & 14.5 & 14. \\
\hline capital (c & NHPB & 9.5 & 9.6 & 9.7 & 9.4 & 10.0 & 10.1 & 9.9 & 10.0 & 10.2 & 10. \\
\hline Equity multiplier & HPB & 9.7 & 9.6 & 9.4 & 8.9 & 8.6 & 8.4 & 8.3 & 8.2 & 8.0 & \\
\hline & NHPB & 11.6 & 11.5 & 11.4 & 11.3 & 11.2 & 11.4 & 11.8 & 12.0 & 12.1 & 11.8 \\
\hline \multicolumn{12}{|l|}{ Profitability } \\
\hline Profit & HPB & 19.3 & 16.9 & 16.0 & 17.8 & 16.4 & 17.2 & 17.5 & 18.4 & 18.3 & 17. \\
\hline $\operatorname{margin}(\%)$ & NHPB & 13.8 & 11.5 & 10.0 & 9.7 & 6.8 & 5.1 & 3.8 & 6.7 & 9.0 & 9. \\
\hline \multirow[t]{2}{*}{ Loss rate (\%) } & HPB & 0.13 & 0.20 & 0.35 & 0.33 & 0.62 & 0.82 & 0.92 & 0.52 & 0.28 & 0.23 \\
\hline & NHPB & 0.35 & 0.41 & 0.65 & 0.80 & 1.28 & 2.18 & 2.41 & 1.30 & 0.74 & 0.51 \\
\hline \multirow{2}{*}{$\begin{array}{l}\text { Net interest } \\
\text { margin (\%) }\end{array}$} & HPB & 4.55 & 4.92 & 4.85 & 4.74 & 4.57 & 4.68 & 4.43 & 4.31 & 4.24 & 4.2 \\
\hline & NHPB & 4.19 & 4.50 & 4.36 & 18 & 4.01 & 4.10 & 3.82 & 3.75 & 3.80 & 3.8 \\
\hline \multirow{2}{*}{$\begin{array}{l}\text { Net noninterest } \\
\text { margin (\%) }\end{array}$} & HPB & 1.90 & 1.98 & -2.03 & -1.99 & 1.95 & -1.96 & -1.97 & -1.93 & -1.93 & -1.9 \\
\hline & NHPB & -2.13 & 2.26 & -2.32 & -2.30 & -2.28 & -2.33 & -2.36 & -2.33 & -2.34 & -2.3 \\
\hline \multicolumn{12}{|l|}{ Adjusted net } \\
\hline interest & $\begin{array}{r}\text { HPB } \\
\text { NHPB }\end{array}$ & & 5.31 & 4.91 & 4.99 & 4.28 & 4.27 & 4.05 & 4.04 & 4.34 & 4.3 \\
\hline & & & & & & & & 2.61 & 3.09 & 3.33 & \\
\hline \multicolumn{12}{|l|}{ Liquidity } \\
\hline \multirow{2}{*}{$\begin{array}{l}\text { Loan-to- } \\
\text { deposit (\%) }\end{array}$} & HPB & 52.5 & 49.3 & 47.7 & 47.8 & 48.6 & 45.7 & 43.3 & 44.7 & 46.5 & 48. \\
\hline & NHPB & 58.2 & 55.9 & 55.7 & 55.9 & 56.7 & 52.9 & 49.2 & 49.4 & 51.4 & 53 \\
\hline \multirow{2}{*}{$\begin{array}{l}\text { Municipals-to- } \\
\text { securities (\%) }\end{array}$} & HPB & 36.8 & 35.6 & 36.3 & 33.1 & 32.1 & 33.5 & 30.4 & 27.9 & 26.2 & 24. \\
\hline & NHPB & 32.7 & 31.6 & 31.3 & 26.2 & 23.2 & 21.2 & 17.2 & 14.1 & 12.7 & 12 \\
\hline \multicolumn{12}{|l|}{ Demand dep- } \\
\hline & HPB & 33.0 & 25.5 & 22.6 & 20.1 & 18.7 & 17.3 & 16.8 & 16.3 & 15.8 & 15. \\
\hline liabilities $(\%)$ & NHPB & 27.8 & 20.3 & 17.7 & 15.0 & 14.0 & 13.0 & 12.9 & 12.8 & 12.2 & 11 \\
\hline \multirow{2}{*}{$\begin{array}{l}\text { Securities -to- } \\
\text { assets (\%) }\end{array}$} & HPB & 37.6 & 40.0 & 42.5 & 44.2 & 43.1 & 43.8 & 44.4 & 45.2 & 44.7 & 43 \\
\hline & NHPB & 31.6 & 33.0 & 33.6 & 35.8 & 34.2 & 34.8 & 36.2 & 38.4 & 38.0 & 36 \\
\hline \multirow{2}{*}{$\begin{array}{l}\text { Efficiency } \\
\text { Debt service (\%) }\end{array}$} & HPB & 294.9 & 315.7 & 294. & 285.7 & 252.0 & & 272.5 & 281.3 & 225.2 & 200.0 \\
\hline & NHPB & 201.2 & 178.9 & 162.0 & 168.1 & 162.1 & 169.9 & 175.4 & 182.3 & 182.0 & 175 \\
\hline \multirow{2}{*}{$\begin{array}{l}\text { Times interest } \\
\text { eamed (times) }\end{array}$} & HPB & 3.06 & 3.26 & 3.0 & 2.9 & 2.6 & 2. & 2.8 & 2.9 & 10 & 2.1 \\
\hline & NHPB & 2.10 & 1.88 & 1.68 & 1.75 & 1.69 & 1.78 & 1.85 & 1.85 & 1.93 & 1.8 \\
\hline \multirow{2}{*}{$\begin{array}{l}\text { Average deposit } \\
\text { rate }(\%)\end{array}$} & HPB & 4.90 & 6.7 & 7.5 & 7.07 & 7.5 & 6. & 5.9 & 5.33 & 5.54 & 6.2 \\
\hline & NHPB & 5.53 & 7.53 & 8.29 & 7.83 & 8.30 & 7.49 & 6.44 & 5.62 & 5.78 & 6.4 \\
\hline \multicolumn{12}{|l|}{ Interest expense-to- } \\
\hline $\begin{array}{l}\text { average } \\
\text { assets (\%) }\end{array}$ & $\begin{array}{r}\text { HPB } \\
\text { NHPB }\end{array}$ & $\begin{array}{l}4.38 \\
5.02\end{array}$ & $\begin{array}{l}6.28 \\
7.14\end{array}$ & $\begin{array}{l}6.95 \\
7.79\end{array}$ & $\begin{array}{l}5.98 \\
6.73\end{array}$ & $\begin{array}{l}6.26 \\
7.03\end{array}$ & $\begin{array}{l}5.60 \\
6.29\end{array}$ & $\begin{array}{l}4.87 \\
5.45\end{array}$ & $\begin{array}{l}4.30 \\
4.75\end{array}$ & 4.43 & $\begin{array}{l}4.9 \\
5.4\end{array}$ \\
\hline \multirow{2}{*}{\multicolumn{12}{|c|}{ Noninterest expense }} \\
\hline & HPB & 2.28 & 2.44 & 2.47 & 2.45 & & & & & & \\
\hline $\begin{array}{l}\text { Lo-avg. } \\
\text { assets }(\%) .\end{array}$ & NHPB & 2.52 & 2.73 & 2.77 & 2.77 & 2.76 & 2.81 & 2.85 & 2.84 & 2.86 & \\
\hline \multirow{2}{*}{$\begin{array}{l}\text { Assets per } \\
\text { employee (\$) }\end{array}$} & HPB & 1,459 & 1,527 & 1,654 & 1,770 & 1,874 & 1,973 & 2,091 & 2,193 & 2,259 & 2,329 \\
\hline & NHPB & 1,348 & 1,387 & 1,509 & 1,612 & 1,688 & 1,757 & 1,825 & 1,875 & 1,910 & 1,951 \\
\hline
\end{tabular}


TABLE 3

High-Performance Bank Logit Model Parameters, By Year

\begin{tabular}{|c|c|c|c|c|c|c|c|c|}
\hline Year & Intercept & LTDG & MTS & RTANIM & DDTL & NIEAA & EM & $\begin{array}{c}C \\
\text { Index }\end{array}$ \\
\hline 1989 & $\begin{array}{r}-3.375 \\
(6.83)\end{array}$ & $\begin{array}{r}-0.028 \\
(4.66)\end{array}$ & $\begin{array}{l}0.045 \\
(8.20)\end{array}$ & $\begin{array}{l}1.214 \\
(9.23)\end{array}$ & $\begin{array}{l}0.045 \\
(3.73)\end{array}$ & $\begin{array}{r}-1.503 \\
(9.52)\end{array}$ & $\begin{array}{r}-0.017 \\
(3.76)\end{array}$ & 0.89 \\
\hline 1988 & $\begin{array}{r}-1.975 \\
(3.13)\end{array}$ & $\begin{array}{r}-0.021 \\
(3.28)\end{array}$ & $\begin{array}{l}0.045 \\
(7.89)\end{array}$ & $\begin{array}{l}1.012 \\
(7.73)\end{array}$ & $\begin{array}{l}0.045 \\
(3.88)\end{array}$ & $\begin{array}{r}-1.399 \\
(8.33)\end{array}$ & $\begin{array}{r}-0.146 \\
(3.62)\end{array}$ & 0.91 \\
\hline 1987 & $\begin{array}{l}-4.815 \\
(9.76)\end{array}$ & $\begin{array}{r}-0.020 \\
(3.124)\end{array}$ & $\begin{array}{l}0.045 \\
(8.23)\end{array}$ & $\begin{array}{r}2.044 \\
(13.31)\end{array}$ & $\begin{array}{l}0.025 \\
(2.34)\end{array}$ & $\begin{array}{r}-2.023 \\
(11.04)\end{array}$ & $\begin{array}{r}-0.040 \\
(7.58)\end{array}$ & 0.92 \\
\hline 1986 & $\begin{array}{r}-2.411 \\
(3.47)\end{array}$ & $\begin{array}{r}-0.018 \\
(2.65)\end{array}$ & $\begin{array}{l}0.044 \\
(8.25)\end{array}$ & $\begin{array}{r}1.864 \\
(11.67)\end{array}$ & $\begin{array}{l}0.002 * \\
(0.22)\end{array}$ & $\begin{array}{r}-1.893 \\
(9.47)\end{array}$ & $\begin{array}{r}-0.246 \\
(5.31)\end{array}$ & 0.93 \\
\hline 1985 & $\begin{array}{r}-1.531 \\
(2.31)\end{array}$ & $\begin{array}{l}-0.028 \\
(4.08)\end{array}$ & $\begin{array}{l}0.041 \\
(8.31)\end{array}$ & $\begin{array}{r}1.426 \\
(10.44)\end{array}$ & $\begin{array}{l}-0.004 *, \neq \\
(0.34)\end{array}$ & $\begin{array}{r}-1.578 \\
(8.09)\end{array}$ & $\begin{array}{r}-.212 \\
(4.49)\end{array}$ & 0.92 \\
\hline 1984 & $\begin{array}{l}-0.550 * \\
(0.82)\end{array}$ & $\begin{array}{l}-0.038 \\
(5.74)\end{array}$ & $\begin{array}{l}0.038 \\
(7.74)\end{array}$ & $\begin{array}{l}0.013 \\
(8.87)\end{array}$ & $\begin{array}{l}0.035 * \\
(0.34)\end{array}$ & $\begin{array}{r}-0.790 \\
(8.09)\end{array}$ & $\begin{array}{r}-0.314 \\
(4.49)\end{array}$ & 0.89 \\
\hline 1983 & $\begin{array}{l}2.525 \\
(4.52)\end{array}$ & $\begin{array}{r}-0.038 \\
(5.90)\end{array}$ & $\begin{array}{r}0.0229 \\
(6.22)\end{array}$ & $\begin{array}{l}0.013 \\
(3.39)\end{array}$ & $\begin{array}{l}0.035 \\
(3.78)\end{array}$ & $\begin{array}{l}-0.790 \\
(5.53)\end{array}$ & $\begin{array}{r}-0.314 \\
(7.75)\end{array}$ & 0.85 \\
\hline 1982 & $\begin{array}{l}2.786 \\
(5.02)\end{array}$ & $\begin{array}{l}-0.038 \\
(5.99)\end{array}$ & $\begin{array}{l}0.019 \\
(4.82)\end{array}$ & $\begin{array}{l}0.085 \\
(2.82)\end{array}$ & $\begin{array}{l}0.026 \\
(3.12)\end{array}$ & $\begin{array}{l}-0.731 \\
(5.59)\end{array}$ & $\begin{array}{l}-0.301 \\
(7.75)\end{array}$ & 0.82 \\
\hline 1981 & $\begin{array}{l}2.482 \\
(4.33)\end{array}$ & $\begin{array}{r}-0.031 \\
(4.72)\end{array}$ & $\begin{array}{l}0.014 \\
(3.61)\end{array}$ & $\begin{array}{l}0.063 \\
(2.37)\end{array}$ & $\begin{array}{l}0.029 \\
(3.74)\end{array}$ & $\begin{array}{l}-0.758 \\
(5.90)\end{array}$ & $\begin{array}{r}-0.284 \\
(7.38)\end{array}$ & 0.80 \\
\hline
\end{tabular}

* Not significant at the 99 percent level confidence level.

$\neq$ Wrong sign.

${ }^{1}$ Model chi-squares and likelihood ratio indices paralleled the $C$ Index. These are available from the authors upon request. 
plier (EM); 5) municipal-to-security ratio (MTS); and 6) adjusted net interest margin (RTANIM). Three of these ratios address the composition of assets and liabilities (LTDG, MTS, DDTL), shedding light on the value of liquidity and risk management. One ratio (RTANIM) highlights the importance of profitability, including tax and risk management. One ratio (NIEAA) captures the contribution of expense control and efficiency. The last ratio (EM) describes the use of leverage and its associated risk and provides an indication of solvency.

Among the annual versions of the national model, only the variable DDTL failed to be significant and to have the correct sign every year. From 1984 to 1986 , DDTL was not statistically significant, and in 1985, it had the wrong sign. In 1984, the intercept was insignificant as well.

Each of the national annual models performed well by the $C$ Index diagnostic. The $C$ Index measures all pairs of the observations having different values for the dependent variables. It compares the predicted probability of each member of the pair and the actual value of that member. Each pair where the higher actual value also has the higher predicted probability is called a "concordant pair." The $C$ Index is the ratio of the number of concordant pairs plus one-half the pairs with tied predicted probabilities to total pairs. The maximum value for this index is one.

Signs on the parameter estimates confirmed results of the ratio analysis section. A higher loan-to-deposit ratio reduced likelihood of high performance. More aggressive lending led to higher loan loss rates and reduced relative performance. A higher proportion of municipal bonds among securities (positively related to high performance) increased tax-exempt income, although undoubtedly at the cost of some liquidity. However, it is likely that banks held U.S. Treasuries, not municipal bonds, for liquidity. High performance was strongly and positively related to net interest margin as adjusted for loan loss rates and taxable equivalent income.

The demand deposit-to-total liability ratio had the correct sign each year in which it was significant. This ratio was an indicator of a bank's ability to hold down deposit interest costs. It also indicated the share of liabilities that were callable upon demand and that would potentially reduce liquidity. These conflicting contributions may have been the reason for the weakness of the significance tests.

Noninterest expense control, reflecting personnel, as well as bricks and mortar, was very important to high performance. This variable was highly correlated with assets per employee as expected. The high-performance banks consistently had more dollars of assets per employee, which resulted in relatively lower expense per dollar of assets at equivalent salary levels. Finally, the equity multiplier, where a higher measure implies greater leverage and therefore greater risk, proved to be inversely related to high performance. This ratio of assets to equity 
declined during the decade for high performers and stayed relatively constant for nonhigh performers.

\section{Regional Level Model Results}

The regional disaggregation of the 204 HPBs and 2,899 NHPBs is illustrated in Figure 1. The Com Belt, Lake States, and Northern Plains regions contain 70 percent of the HPBs and 79 percent of the NHPBs in the nation. The Northeast and Pacific regions contain only 1 HPB and 21 NHPBs. The paucity of qualifying banks in these regions reflects the less credit-intensive type of agricultural production found in the Northeast region and the bank branching and bank size in the Pacific region, among other factors.

\section{FIGURE 1}

Number of HPBs and Non-HPBs by USDA Crop Reporting Region

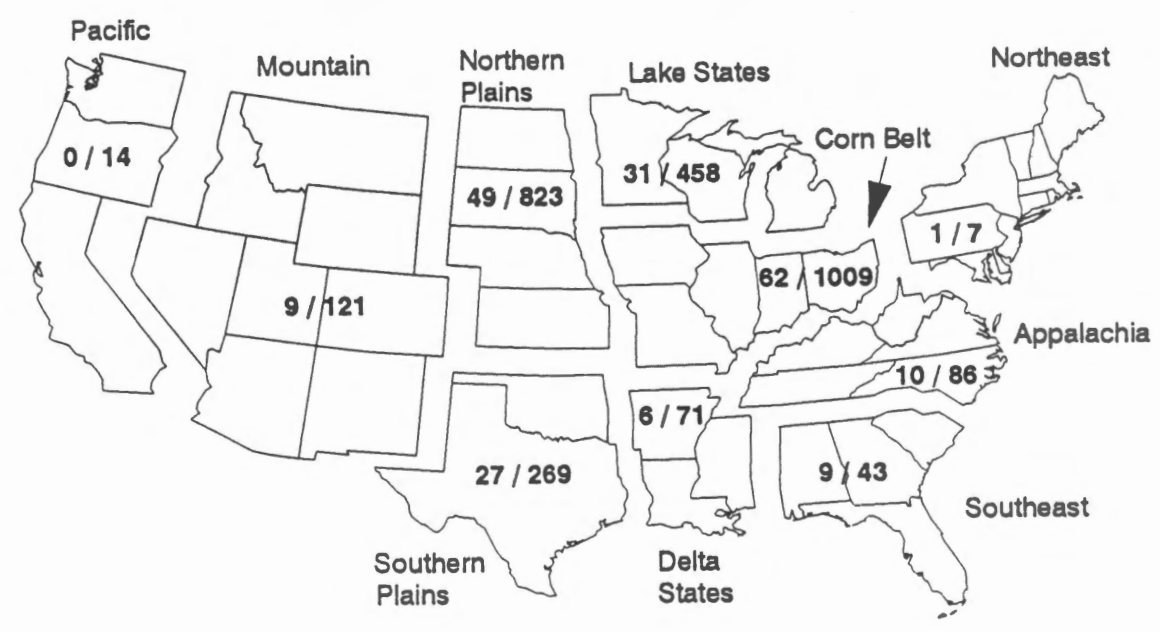

The model was estimated annually in each of four regions: Northem Plains, Lake States, Corn Belt, and Southern Plains. The annual estimations at the regional level produced mixed results. Most variables had the correct signs each year with the exception of DDTL in the Lake States. DDTL had the wrong sign in seven out of nine years in the Lake States, but was not statistically significant in any year. DDTL was the variable that performed most poorly in the annual regional models.

Lack of significance was a problem with every variable parameter estimate at some point during the annual estimation process at the regional level. However, variable signs were wrong only three times, and the corresponding parameter estimates were significant. These occurred for EM in the Com Belt in 
1983 and in the Northern Plains in 1982 and 1983. EM was also a very poor explanatory variable in the model of the Southern Plains region, being insignificant during all but one year. In four other instances, parameter estimates had wrong signs, but the $t$-tests were insignificant.

Parameter estimates derived by aggregating the data from 1981 to 1989 and by estimating the same model at both the national and regional levels are presented in Table 4 with model diagnostics. The national model is highly significant, the parameter estimates all have the correct signs, the t-statistics (in parenthesis) are significant, and the $\mathrm{C}$ Index is very good.

TABLE 4

Comparison of National and Regional Model Estimates

\begin{tabular}{lccccccccc}
\hline \hline & & & & & & & & \\
Area & Intercept & LTDG & MTS & RTANIM & DDTL & NIEAA & EM & $\begin{array}{c}\text { C } \\
\text { Index }\end{array}$ \\
\hline All & 0.788 & -0.030 & 0.026 & 0.277 & 0.029 & -0.869 & -0.188 & 0.86 \\
& $(4.85)$ & $(14.73)$ & $(18.48)$ & $(13.94)$ & $(9.85)$ & $(18.95)$ & $(16.04)$ & \\
Lake States & 1.344 & -0.060 & 0.043 & 0.367 & $-0.024^{*}, \neq$ & -1.054 & -0.027 & 0.86 \\
& $(3.161)$ & $(10.03)$ & $(10.26)$ & $(6.82)$ & $(1.36)$ & $(7.93)$ & $(1.81)$ & \\
Corn Belt & 3.212 & -0.016 & 0.032 & 0.196 & 0.046 & -0.948 & -0.533 & 0.90 \\
& $(9.64)$ & $(3.81)$ & $(9.87)$ & $(5.04)$ & $(6.37)$ & $(9.25)$ & $(19.82)$ & \\
Northern & 2.271 & -0.042 & 0.021 & 0.168 & 0.048 & -1.273 & -0.165 & 0.85 \\
Plains & $(6.67)$ & $(9.83)$ & $(6.00)$ & $(5.07)$ & $(7.97)$ & $(12.76)$ & $(6.96)$ & \\
Southern & -2.006 & -0.026 & 0.017 & 0.344 & $0.012 *$ & -0.401 & -0.010 & 0.76 \\
Plains & $(6.31)$ & $(5.18)$ & $(5.36)$ & $(6.16)$ & $(1.90)$ & $(4.11)$ & $(1.96)$ & \\
\hline
\end{tabular}

* Not significant at the 99 percent confidence level.

$\neq$ Wrong sign.

${ }^{2}$ Model chi-squares and likelihood ratio indices parallelled the C Index. These are available from the authors upon request.

The regional-level model parameter estimates are in conformity with national estimates. In the Lake States for DDTL, there is a difference in sign, but it is statistically insignificant. Also, the parameter estimates for EM in the Lake States and for DDTL in the Southern Plains are statistically insignificant. Parameter values vary from region to region, but this variation was expected. In general, the regional models were statistically significant, but the Southern Plains regional model was weak. The $C$ Index measure and the likelihood ratio index were substantially lower than either the national or other regional models.

Table 5 demonstrates the impact of a one-unit change in each of the variables (while holding all others constant) on the probability of a bank's being a high performer in the national model. The model is evaluated at the variable means to 
TABLE 5

Effect of One Unit Change in Independent Variable on Probability of High Performance

\begin{tabular}{lcc}
\hline \hline Variable & Probability & $\begin{array}{c}\text { Change in } \\
\text { Probability }\end{array}$ \\
\hline LTDG & .0322 & -.00095 \\
DDTL & .0341 & +.00095 \\
NIEAA & .0142 & +.01895 \\
EM & .0276 & +.00551 \\
MTS & .0340 & -.00086 \\
RTANIM & .0432 & -.01012 \\
& & - \\
Model & .0331 & - \\
\hline
\end{tabular}

generate the model probability of 0.0331 , from which each change in probability is estimated (Judge et al. 1982). The variables generating the largest response are NIEAA (the expense control variable) and RTANIM (profitability adjusted for risk and tax considerations).

\section{CONCLUSIONS AND IMPLICATION}

In spite of the decline in the agricultural sector during the mid-1980s, 204 banks extended an above-average share of their loans to farmers and eamed a superior rate of retum on average assets every year of the decade. When compared to the 2,899 agricultural banks that earned significantly lower returns on average assets, adherence to traditional banking practices appeared to explain most of the difference in performance. HPBs were more concemed with loan quality, thus making fewer risky loans and fewer loans overall. They maintained high levels of liquidity and safety by holding higher securities-to-assets ratios and by keeping a higher proportion of those securities in municipal bonds. HPBs controlled interest expense better by paying a lower average interest rate on deposits. They were also more efficient at controlling noninterest expenses and had a better balance between noninterest income and noninterest expense. There were no significant deviations between national results and those at the USDA crop reporting regional level.

A logit model was estimated to evaluate factors leading to classification of agricultural banks as high-performance banks. The model performed well at both the national and regional levels, using aggregate data across the decade. The model shows promise for allowing evaluation of bank management performance 
on both national and regional levels. When estimated using annual data, the model performed well at the national level but less well at the regional level. This was not unexpected because regional agricultural differences, as well as bank regulatory factors, influence bank performance.

Studies by Ford and Olsen, Gup and Walker, and Clair obtained results that were consistent with this study's conclusion that traditional banking practices led to high performance. However, these studies were more general in nature and did not control for a consistent set of banks. Furthermore, they used time periods that either could not discount random events or did not capture a full economic cycle at the national or sector level.

Because of their concentration in lending to agriculture, the banks in this study are mostly located in rural areas. Their credit market competitors thus tend to differ in some respects from those of urban banks. For example, agricultural banks normally compete with the Cooperative Farm Credit System, other banks their size, and captive finance companies (that operate through local product distributors) for borrowers. In an urban environment, the same sized bank might be competing against a range of different sized banks, credit unions, savings and loans, mutual funds, and other finance companies. This difference may caution against generalizing the research results to nonagricultural banks.

Further research is in progress to determine whether these results can be applied to banks specializing in lending to other sectors. One important factor in the revival of NHPBs was the massive level of federal assistance to farmers during the mid- to late-1980s. Other sectors, such as commercial real estate, do not have similar governmental support, and the impact of the decline in the commercial real estate sector and of the banks lending to it is now becoming apparent. However, just as a group of HPBs existed during the decline in agriculture, it is expected that a group of HPBs will be found that specialize in real estate and that apply traditional lending practices.

The implication of the study is that local agricultural banks can do a superior job of evaluating credit risk, which will hold them in good stead as the impacts of deregulation and increased competition continue to spread. However, these banks need to be vigilant in maintaining credit standards and controlling costs. Commercial banks can continue to be very important providers of agricultural credit, even through cyclical downturns, if they adhere to traditional bank lending maxims. The results of the current study are significant because major changes in banking structures are being discussed. The above results are not necessarily consistent with the premises upon which current proposals to restructure banking are based. 


\section{REFERENCES}

Bovenzi, J. F., J. A. Marino, and F. McFadden. "Commercial Bank Failure Prediction Models." Economic Review (Federal Reserve Bank of Atlanta) 68 (1983):14-26.

Clair, R. T. "Financial Strategies of Top-Performance Banks in the Eleventh District." Economic Review (Federal Reserve Bank of Dallas) (January 1987): 1-14.

Duncan, D. G., G. R. Gajewski, and M. E. Burkhart. "Farm Banks in the Energy Belt A Double Whammy?" Agricultural Finance Review 50 (1990):112-125.

Ford, W. F., and D. A. Olson. "How 1000 High Performance Banks Weathered the Recent Recession." Banking (April 1978): 36-48.

Gajewski, G. R. "Agricultural Lending, Regulator Behavior, and Bank Closures in 1986: A Two-stage Logit Model." Paper presented at the Eastem Economic Association, Washington, D.C., 1987.

Goldman, Sachs. Investments Research. 2nd Quarter (1987): 6-7.

Gup, B. E., and J. R. Walter. "Top Performing Small Banks: Making Money the Old-Fashioned Way." Economic Review (Federal Reserve Bank of Richmond) (November/December 1989): 23-35.

Judge, G. G., R. C. Hill, W. E. Griffiths, H. Lutkepohl, and T. Lee. Introduction to the Theory and Practice of Econometrics. New York: John Wiley \& Sons, 1982.

Pindyck, R. S., and D. L. Rubinfeld. Econometric Models and Economic Forecasts. 2nd ed. New York: McGraw-Hill, Inc., 1981.

Melichar, E. "Turning the Comer On Troubled Farm Debt." Federal Reserve Bulletin (July 1987): 523-36.

Sinkey, J. F., Jr. Commercial Bank Management in the Financial Services Industry. 3rd ed. New York: MacMillian, 1989.

Whalen, G. "Concentration and Profitability in Non-SMA Banking Markets." Economic Review (Federal Reserve Bank of Cleveland) Quarter 1 (1987): 2-9. 